\title{
Protein Turnover Rates in Sick, Premature Neonates during the First Few Days of Life
}

\author{
SALLY G. MITTON, A. GRAHAM CALDER, AND PETER J. GARLICK \\ Department of Child Health. Westminster Children's Hospital, London, United Kingdom [S.G.M.] and Rowett \\ Research Institute, Aberdeen, United Kindom [A.G.C., P.J.G.]
}

\begin{abstract}
Rates of protein turnover were measured in 19 infants during the first few days of life while they were receiving i.v. glucose. The technique consisted of a continuous i.v. infusion of $\mathrm{L}-\left[1-{ }^{13} \mathrm{C}\right] \mathrm{leucine}$ to measure whole body leucine flux and determination of total urinary nitrogen excretion to assess leucine oxidation rates. Subsequent to each of the studies, the decision to start total parenteral nutrition (TPN) was made by the clinician concerned, with the result that seven infants did not start TPN and 12 did. There were significantly greater urinary nitrogen excretion $(p<0.001)$ and lower rates of whole body protein synthesis $(p=0.024)$ and breakdown $(p=0.015)$ in those who did start TPN compared with those who did not. The marked difference in nitrogen excretion between the two groups suggests that this could be a useful determinant for deciding which neonate should start TPN. (Pediatr Res 30: 418422,1991 )
\end{abstract}

\section{Abbreviations}

TPN, total parenteral nutrition

LBWN, low birth weight neonate

$\mathrm{N}$, nitrogen

TBUN, total body urea nitrogen

The decision to start TPN in the sick LBWN is usually made on clinical grounds as well as objective parameters such as metabolic or nutritional status. Although it is undeniable that this group of infants requires adequate and appropriate nutrition for optimal development (1), the immaturity of their metabolic pathways (2) may limit tolerance to the solutions used in TPN. Some of these problems, such as acidosis (3) and hyperammonemia (4), have diminished because protein hydrolysates have been replaced by crystalline amino acid solutions. It is, nonetheless, prudent to consider with care the administration of TPN in the early postnatal days. One approach that could be used to recognize LBWN at particular nutritional risk would be to identify those who are becoming increasingly catabolic.

The purpose of this study was to collect values for rates of protein turnover from LBWN receiving i.v. glucose in the early postnatal period before the decision was made as to whether these neonates should start TPN. There have been few studies of whole body protein turnover in the newborn, and these have produced a wide range of values, ranging from 5 to $26 \mathrm{~g} / \mathrm{kg} / \mathrm{d}$ for protein synthesis $(5,6)$. Most of the studies have used $\left[{ }^{15} \mathrm{~N}\right]$ glycine, because this procedure requires measurements only on

Received December 14, 1990; accepted May 20, 1991.

Correspondence and reprint requests: Dr. S. G. Mitton, M.B., M.R.C.P., Dept of Child Health, Westminster Children's Hospital, Vincent Square, London, SWIP 2NS, England.

Supported in part by Children Nationwide Medical Research Fund and Westminster Medical School Research Trust. urine and, therefore, is noninvasive. With this method, the calculation of whole body protein turnover involves quantifying $\mathrm{N}$ kinetics per se. The alternative is to use a selected "representative" amino acid labeled with a stable isotope and, by measuring dilution of this tracer, to derive values for the metabolic turnover of that particular amino acid (7). L- $\left[1-{ }^{13} \mathrm{C}\right]$ leucine is one such tracer that has been used to measure protein turnover in premature infants (8). This method is more invasive, in that blood samples are generally used, but in the study presented here this was possible because the infants had indwelling arterial catheters. However, a further restriction is the need for breath $\mathrm{CO}_{2}$ collection to assess leucine oxidation. We have therefore modified the constant infusion of $\left[1-{ }^{13} \mathrm{C}\right]$ leucine method for measuring whole body protein turnover rates by using $\mathrm{N}$ excretion to assess leucine oxidation. The results show differences between those infants who subsequently did or did not start TPN.

\section{MATERIALS AND METHODS}

Patients. Nineteen infants, gestational ages $30.4 \pm 1.2 \mathrm{wk}$ (mean $\pm \mathrm{SD}$ ) and weight $1.48 \pm 0.30 \mathrm{~kg}$, were studied between 17 and $91 \mathrm{~h}$ postnatal age $(46 \pm 17 \mathrm{~h})$. Infants were studied only if they had an i.v. cannula in situ; all were given i.v. glucose and had similar energy intakes. None were enterally fed at the time of study. Only male infants were studied because of the need for accurate urine collection. Exclusion criteria were the presence of any metabolic disorders, renal failure, and insulin administration. Informed parental consent was obtained in all cases, and the study had the approval of the local ethics committee. The clinical characteristics of all infants are listed in Table 1. The infants were of appropriate birth weight for gestational age (9) except for cases 4, 7, and 17. All required varying degrees of ventilatory support for respiratory distress. Subsequently, seven infants were not started on TPN (group A) and 12 did start TPN (group B). The decision to start TPN was made independently by the clinician concerned, so the researcher was not involved. There was a clinical assessment of the duration of time that intensive care support would be required, which included whether a particular neonate was likely, because of the severity of the illness, to tolerate sufficient enteral feeds to provide adequate nutrition. A trial of enteral feeding was given when the infant was stable and it was considered appropriate.

Stable isotope administration and nitrogen balance. The infants were given a 6 -h i.v. infusion of $\left[1-{ }^{13} \mathrm{C}\right]$ leucine at a dose of $6.1 \mu \mathrm{mol} / \mathrm{kg} / \mathrm{h}$, preceded by a priming dose of $15.3 \mu \mathrm{mol} / \mathrm{kg}$. Priming the infusion reduces the time taken to achieve plateau to a maximum of $2 \mathrm{~h}$ in adults (10). Heparinized blood samples $(0.5 \mathrm{~mL})$ were collected at $0,2,4$, and $6 \mathrm{~h}$ from indwelling arterial lines and immediately separated by centrifugation, and the plasma was stored at $-20^{\circ} \mathrm{C}$ until analysis. A timed urine collection of about $12 \mathrm{~h}$ duration was started at the beginning of the infusion, using a closed circuit driven by a constant air pump, a modification of a method described previously (11). This enabled air to be continually blown into the urine bag, preventing 
Table 1. Clinical characteristics of infants*

\begin{tabular}{|c|c|c|c|c|c|c|c|c|}
\hline \multirow[b]{2}{*}{ Patient } & \multirow{2}{*}{$\begin{array}{l}\text { Gest age } \\
(w k+d)\end{array}$} & \multirow{2}{*}{$\begin{array}{l}\text { Birth wt } \\
(\mathrm{kg})\end{array}$} & \multirow{2}{*}{$\begin{array}{c}\text { Age at } \\
\text { study }(\mathrm{h})\end{array}$} & \multirow{2}{*}{$\begin{array}{l}\text { Wt change } \dagger \\
(\mathrm{g} / \mathrm{kg} / \mathrm{d})\end{array}$} & \multirow{2}{*}{$\begin{array}{c}\text { Duration } \\
\text { of vent }\end{array}$} & \multicolumn{2}{|c|}{$N / G$ feeds } & \multirow{2}{*}{$\begin{array}{c}\text { Energy intake } \\
(\mathrm{kcal} / \mathrm{kg} / \mathrm{d})\end{array}$} \\
\hline & & & & & & Start & Full & \\
\hline \multicolumn{9}{|c|}{ Group $\mathrm{A}$-neonates not subsequently started on TPN } \\
\hline 1 & 32 & 1.64 & 91 & -11 & D 2-4 & D 5 & D 8 & 35 \\
\hline 2 & 31 & 1.79 & 32 & -4 & None & D 3 & D 7 & 35 \\
\hline 3 & 31 & 1.48 & 48 & -10 & None & D 3 & D 5 & 36 \\
\hline $4 \ddagger$ & $29+4$ & $0.908 \S$ & 36 & -18 & $17 \mathrm{~h}$ & D 3 & $?$ & 33 \\
\hline 5 & 28 & 1.54 & 51 & -36 & D $0-4$ & D 5 & D 8 & 44 \\
\hline 6 & 31 & 1.77 & 64 & -31 & $<24 \mathrm{~h}$ & D 3 & D 4 & 17 \\
\hline 7 & 31 & $1.2 \S$ & 56 & -2 & D $0-2$ & D 5 & D 6 & 40 \\
\hline Mean $\pm S D$ & $30.8 \pm 0.7$ & $1.47 \pm 0.3$ & $53.6 \pm 18$ & $-16 \pm 13$ & $33 \pm 33$ & $5 \pm 1$ & $6 \pm 1.5$ & $34.3 \pm 8.5$ \\
\hline \multicolumn{9}{|c|}{ Group B-those subsequently started on TPN } \\
\hline 8 & $32+3$ & 1.74 & 44 & -34 & $\mathrm{D} 0-3$ & D 7 & D 9 & 34 \\
\hline $9 \|$ & $30-31$ & 1.39 & 33 & -65 & D $1-3$ & D 7 & D 14 & 34 \\
\hline 10 & $30+6$ & 1.34 & 43 & -1 & D $0-16$ & $\mathrm{D} 10$ & D 15 & 40 \\
\hline 119 & $30+3$ & 1.536 & 46 & -16 & D $0-47$ & D 22 & D 26 & 40 \\
\hline $12 * *$ & $30+5$ & 1.7 & 24 & +45 & $\mathrm{D} 0-16$ & D 12 & D 25 & 34 \\
\hline $13^{* *}$ & $30+5$ & 1.754 & 47 & -20 & D $0-16$ & D 16 & D 18 & 34 \\
\hline $14+\dagger$ & $33+5$ & 1.967 & 43 & $\mathrm{~N} / \mathrm{W}$ & D 0-9 & D 11 & D 17 & 36 \\
\hline 15 & 30 & 1.435 & 17 & -10 & $24 \mathrm{~h}$ & D 3 & D 4 & 25 \\
\hline $16 t t$ & 29 & 1.202 & 24 & $N / W$ & D $0-10$ & & & 40 \\
\hline $17 \S \S$ & 28 & $0.832 \S$ & 52 & -26 & D 0-7 & D 11 & D 15 & 36 \\
\hline 18\|\| & 32 & 1.63 & 48 & +11 & D $0-25$ & D 40 & D 43 & 30 \\
\hline $199 \pi$ & $28+6$ & 1.28 & 69 & -10 & D $0-8$ & D 8 & D 10 & 40 \\
\hline Mean $\pm \mathrm{SD}$ & $30.3 \pm 1.7$ & $1.48 \pm 0.3$ & $41 \pm 14$ & $-12.6 \pm 28$ & $13 \pm 13$ & $13 \pm 10$ & $18 \pm 10$ & $35.2 \pm 4.6$ \\
\hline
\end{tabular}

* Gest age, gestational age; vent, ventilation; N/W, not weighed; N/G, nasogastric; D, day.

$\dagger$ Weight change from birth until day of study.

$\ddagger$ Transferred to another hospital on d 4. Maternal pyrexia in labor, negative infection screen in infant.

$\S$ Small for gestational age (9).

II Increased respiratory distress on d 4; right middle lobe consolidation.

I Negative infection screen; maternal high vaginal swab grew $\beta$-hemolytic streptococcus; later developed bronchopulmonary dysplasia.

** Twins. Both had multiple pneumothoraces. No. 12, last chest drains out d 7 ; no. 13 , d 13. No. 12 still in $23 \% \mathrm{O}_{2}$ by $\mathrm{d} 23$, day transferred to another hospital.

$\dagger \uparrow$ Multiple pneumothoraces; last chest drain out d 12; good outcome.

枺 Multiple pneumothoraces; died d 10.

$\S \S$ Maternal systemic lupus erythematosis.

III Ventricular septal defect without cardiac failure. Intestinal obstruction $\mathrm{d} 7$, perforated $\mathrm{d} 9$.

กा Metabolic acidosis $\mathrm{d} 4$ and 6 ; negative infection screens.

development of a vacuum, while the urine was sucked into a dependent syringe outside the incubator. A further $0.2 \mathrm{~mL}$ of blood was taken at 0 and $12 \mathrm{~h}$ for plasma urea concentration measurements, to correct $\mathrm{N}$ excretion values for any change in TBUN during the urine collection (12).

Laboratory analyses. ${ }^{13} \mathrm{C}$ enrichment was measured with a VG 12-250 gas chromatograph-mass spectrometer (VG Masslab, Manchester, UK) after conversion to the tertiarybutyldimethylsilyl derivative. The ion peaks measured were $\mathrm{m} / \mathrm{e} 302$ and 303 . The total $\mathrm{N}$ content of urine was determined by the Kjeldahl method (13). Plasma urea measurements were made using a urease method on a Boehringer Mannhiem Hitachi 717 (Lewes, East Sussex, UK).

Calculation of whole body turnover rates. The basic principles have been described previously (7). The plasma free amino acid pool is assumed to be in continuous and instantaneous equilibrium with the intracellular pool, which together compose a single homogenous pool exchanging with body protein. Leucine enters the pool from the diet (I) and from the degradation of whole body protein (D) and leucine exit is by protein synthesis (S) and leucine oxidation $(\mathrm{O})$. Therefore, in the steady state,

$$
\mathrm{Q}=\mathrm{I}+\mathrm{D}=\mathrm{S}+\mathrm{O}
$$

where $Q$ is the total turnover rate of the free leucine pool, termed the leucine flux (7). $Q$ is calculated from the isotopic enrichment of the free leucine in plasma after a plateau value (Ep, atom \% excess) has been reached.

$$
\mathrm{Q}=\mathrm{i} \times\left(\frac{\mathrm{Ei}}{\mathrm{Ep}}-1\right) \mu \mathrm{mol} / \mathrm{kg} / \mathrm{h}
$$

where $\mathrm{i}$ is the $\mathrm{L}-\left[1-{ }^{13} \mathrm{C}\right]$ leucine infusion rate $(\mu \mathrm{mol} / \mathrm{kg} / \mathrm{h})$ and $\mathrm{Ei}$ is the enrichment of $\mathrm{L}-\left[1-{ }^{13} \mathrm{C}\right]$ leucine infused (atom $\%$ excess). Dietary intake in these infants being nil, the values for flux equal those for protein breakdown. Leucine oxidation rates were calculated, indirectly, from measurements of total urinary $\mathrm{N}$ (corrected as described below). The ratio of leucine oxidized to total $\mathrm{N}$ in the urine was assumed to be the same as the proportion of leucine in body protein $\mathrm{N}$; a value of $3.817 \mathrm{mmol} / \mathrm{g} \mathrm{N}$ was used for the latter, an average derived from a variety of animals and different tissues (14).

Correction of $N$ excretion for any change in TBUN. Any change in the TBUN ( $\delta$ TBUN) occurring during the urine collection period was added to the amount of measured $\mathrm{N}$ excretion and was calculated as follows:

$$
\delta \mathrm{TBUN}=[(\mathrm{U} 2-\mathrm{U} 1) \times \mathrm{TBW}] / 0.92(\mathrm{mg})
$$

where $\mathrm{U} 1$ and $\mathrm{U} 2$ are plasma urea concentrations ( $\mathrm{mg} \mathrm{N} / \mathrm{L})$ at the beginning and end of the urine collection, respectively; TBW is total body water, which was calculated by assuming the body composition of LBWN at this gestational age to be $80 \%$ water (15); and 0.92 is the factor to correct for plasma containing $92 \%$ water. 
Statistical analysis. Values are given as mean $\pm \mathrm{SD}$, and the analysis was performed by $t$ test (two-tailed).

\section{RESULTS}

There was no difference in gestational age, birth weight, and postnatal age between groups $\mathrm{A}$ and $\mathrm{B}$ (Table 1). Infants in group B were judged to be clinically "sicker" than those in group A. This was confirmed subsequently; for example, the mean duration of ventilation for group A was $33 \mathrm{~h}$ (range 0 to $4 \mathrm{~d}$ ) and for group B, $13.3 \mathrm{~d}$ ( 1 to $47 \mathrm{~d}$ ) and enteral feeding was started on d $5 \pm 1$ for group $A$ and $13 \pm 10$ for group B. One infant (no. 16) died.

Although the weight change between the two groups was not significantly different, there was considerable variation between individuals. The large shifts in water volume in the newborn, particularly the premature, may obscure interpretation of this variable (16). In contrast, urinary $\mathrm{N}$ excretion was significantly greater $(p<0.001)$ in group B than in group A. Correction of this value for any change in TBUN during the urine collection resulted in an average difference in excretory $\mathrm{N}$ production of $1.5 \mathrm{mg} / \mathrm{kg} / \mathrm{h}$ (Table 2). The resulting values for corrected $\mathrm{N}$ excretion showed no overlap between groups.

Plateau values for leucine enrichment in plasma were reached by $2 \mathrm{~h}$ and sustained until $6 \mathrm{~h}$, as shown by the mean values $( \pm$ SD) of $4.29 \pm 0.97$ and $4.29 \pm 0.95$ atom \% excess, at 2 and 6 $\mathrm{h}$, respectively. The coefficient of variation for the plateau (i.e. the difference between 2- and 6-h values, expressed as a percentage of their mean) was 4.9 and $2.8 \%$. The values for leucine oxidation, protein synthesis, and protein breakdown are shown in Table 3. In both groups, the results for protein synthesis rates were lower than those for protein breakdown because balance was negative, but less so in group A compared with group B. Rates for both protein synthesis and breakdown were significantly higher in group A compared with group B ( $p=0.024$ and

Table 2. Changes in total body urea and measured and corrected $N$ excretion (exn)

\begin{tabular}{cccc}
\hline Patient no. & $\begin{array}{c}\text { Changes in } \\
\text { TBUN }(\mathrm{mg})\end{array}$ & $\begin{array}{c}\text { Measured } \\
\mathrm{N} \text { exn } \\
(\mathrm{mg} / \mathrm{kg} / \mathrm{h})\end{array}$ & $\begin{array}{c}\text { Corrected } \\
\mathrm{N} \text { exn } \\
(\mathrm{mg} / \mathrm{kg} / \mathrm{h})\end{array}$ \\
\hline Group A & & & \\
1 & -7.8 & 2.9 & 2.6 \\
2 & -64.4 & 4.8 & 1.7 \\
3 & -10.5 & 2.0 & 1.3 \\
4 & -10.8 & 3.6 & 3.6 \\
5 & -107.2 & 7.0 & 0.4 \\
6 & 16.6 & 3.2 & 3.8 \\
7 & 5.8 & 3.0 & 3.4 \\
Mean \pm SD & $-25.5 \pm 44 \dagger$ & $3.8 \pm 1.6 \dagger$ & $2.4 \pm 1.3 \ddagger$ \\
Group B & & & \\
8 & -21.1 & 5.4 & 5.1 \\
9 & 46.1 & 5.7 & 8.5 \\
10 & 29.3 & 4.5 & 6.5 \\
11 & -18.7 & 5.4 & 4.1 \\
12 & -17.4 & 5.2 & 4.1 \\
13 & 4.2 & 4.4 & 4.5 \\
14 & -14.4 & 8.4 & 7.6 \\
15 & 24.3 & 3.6 & 6.2 \\
16 & -2.9 & 4.4 & 4.2 \\
17 & -10.1 & 5.2 & 4.2 \\
18 & 20.7 & 2.8 & 4.0 \\
19 & -30.2 & 6.9 & 4.8 \\
Mean \pm SD & $0.8 \pm 24 \dagger$ & $5.2 \pm 1.5 \dagger$ & $5.3 \pm 1.5 \ddagger$ \\
\hline
\end{tabular}

* Group A, neonates not subsequently started on TPN; group b, those subsequently started on TPN.

$\dagger$ Group A $v s$ B, NS

$\ddagger$ Group $A$ vs $B, p<0.001$
Table 3. Leucine oxidation and protein synthesis and breakdown

\begin{tabular}{cccc}
\hline Patient no. & $\begin{array}{c}\text { Protcin } \\
\text { synthesis } \\
(\mu \mathrm{mol} / \mathrm{kg} / \mathrm{h})\end{array}$ & $\begin{array}{c}\text { Protein } \\
\text { breakdown } \\
(\mu \mathrm{mol} / \mathrm{kg} / \mathrm{h})\end{array}$ & $\begin{array}{c}\text { Leucine } \\
\text { oxidation } \\
(\mu \mathrm{mol} / \mathrm{kg} / \mathrm{h})\end{array}$ \\
\hline Group A & & & \\
1 & 152 & 163 & 9.9 \\
2 & 142 & 148 & 6.5 \\
3 & 146 & 152 & 5.0 \\
4 & 164 & 175 & 10.3 \\
5 & 267 & 269 & 1.5 \\
6 & 133 & 149 & 14.5 \\
7 & 140 & 155 & 13.0 \\
Mean $\pm \mathrm{SD}$ & $163 \pm 47 \dagger$ & $173 \pm 43 \$$ & $8.7 \pm 4.6 \S$ \\
Group B & & & 19.5 \\
8 & 102 & 124 & 32.4 \\
9 & 121 & 158 & 24.8 \\
10 & 158 & 186 & 15.6 \\
11 & 101 & 119 & 16.0 \\
12 & 95 & 113 & 17.2 \\
13 & 99 & 118 & 29.0 \\
14 & 102 & 134 & 23.7 \\
15 & 104 & 131 & 16.0 \\
16 & 100 & 118 & 16.0 \\
17 & 97 & 115 & 15.3 \\
18 & 114 & 131 & $20.3 \pm 5.8 \S$ \\
19 & 95 & 117 & $130 \pm 21 \ddagger$ \\
Mean $\pm \mathrm{SD}$ & $108 \pm 19 \dagger$ & 15.3 & \\
\hline
\end{tabular}

* Group A, neonates not subsequently started on TPN; group $b$, those subsequently started on TPN.

$\dagger$ Group A vs B, $p=0.024$.

$\ddagger$ Group A $v s \mathrm{~B}, p=0.015$.

$\S$ Group A vs B, $p=0.001$.

0.015 , respectively). There was no correlation for rates of urinary $\mathrm{N}$ excretion, protein synthesis and breakdown with gestational age, birth weight, or postnatal age for the 19 infants taken together.

\section{DISCUSSION}

This study has demonstrated that LBWN who were subsequently given nutritional support had lower rates of whole body protein turnover and higher $\mathrm{N}$ excretion than those who did not. To measure rates of whole body protein turnover, we chose to use a primed, constant infusion of $\left[1-{ }^{13} \mathrm{C}\right]$ leucine. The alternative method, administration of $\left[{ }^{15} \mathrm{~N}\right] g l y c i n e$, has been criticized because 1) there is the possibility that glycine is an indispensible amino acid in the rapidly growing preterm infant (17) and 2) there is a substantial amount of urea in mothers' breast milk (18). When $\left[1-{ }^{13} \mathrm{C}\right]$ leucine is used, one problem is the necessity of measuring leucine oxidation rates to assess the contributions of oxidation and protein synthesis to whole body leucine turnover. This has generally been calculated by measuring the rate of production of labeled $\mathrm{CO}_{2}$, which must include a value for the proportion of retained, labeled $\mathrm{CO}_{2}$. This is greater in infants than in adults (19) and may alter with food intake (20), and acidbase balance, frequently changing in LBWN, could alter $\mathrm{CO}_{2}$ retention. Therefore, recovery rates for $\mathrm{CO}_{2}$ should be determined rather than assumed (21), but this measurement is subject to considerable error. In addition, accurate collection of expired $\mathrm{CO}_{2}$ in a ventilated premature infant requires an airtight seal, which might obstruct access to the sick infant.

In a previous study of protein turnover in premature infants using $\left[1-{ }^{13} \mathrm{C}\right]$ leucine $(8)$, leucine oxidation rates, calculated directly by measuring ${ }^{13} \mathrm{CO}_{2}$ production rates, correlated well with indirect assessments from simultaneous $\mathrm{N}$ excretion measurements. It should, therefore, be possible to dispense with the calculation of leucine oxidation rates from ${ }^{13} \mathrm{CO}_{2}$ production if 
simultaneous measurements of $\mathrm{N}$ excretion were performed, and, in view of the short time of the urine collection, appropriate correction for the change in TBUN should be made. Therefore, for both practical and theoretical reasons, we chose to use this approach, which was found to be readily applicable in the setting of neonatal intensive care.

The mean value for protein synthesis in this group of 19 infants was $128 \mu \mathrm{mol} / \mathrm{kg} / \mathrm{h}$, which, assuming that leucine comprises $8 \%$ of whole body protein by weight (14), corresponds to $5 \mathrm{~g}$ protein $/ \mathrm{kg} / \mathrm{d}$. Even allowing for the fact that values for the healthier infants (group A) were higher than those for group B (6.5 and $4.2 \mathrm{~g}$ protein $/ \mathrm{kg} / \mathrm{d}$, respectively), the rates are lower than others reported for premature infants. The other study that used $\left[1-{ }^{13} \mathrm{C}\right]$ leucine reported a mean value for protein synthesis of $11.5 \mathrm{~g} / \mathrm{kg} / \mathrm{d}(8)$, but this was for healthy, growing, premature infants receiving breast or bottle feeds, whereas the infants in the study presented here received only glucose. Similar high rates were obtained in fed preterm infants, studied with $\left[{ }^{15} \mathrm{~N}\right]$ glycine, when values of $10.9,11.2$, and $13.5 \mathrm{~g} / \mathrm{kg} / \mathrm{d}$ have been reported $(17,22,23)$. A further study in parenterally fed preterm infants with $\left[{ }^{15} \mathrm{~N}\right]$ glycine reported a mean value of $8.8 \mathrm{~g} / \mathrm{kg} / \mathrm{d}(24)$. The same group studied infants sequentially, first when fed parenterally and then enterally, and found that protein synthesis rates were $40 \%$ higher with enteral feeding (25). By contrast, very high rates for protein synthesis, $26 \mathrm{~g} / \mathrm{kg} / \mathrm{d}$, were reported in one study with $\left[{ }^{15} \mathrm{~N}\right]$ glycine (6), but this has been criticized for methodologic reasons (17). These data suggest that the lower rates obtained in the study presented here result from the lack of dietary protein, and lack of enteral feeding may have contributed. This is consistent with the reduction in rates of tissue protein synthesis that occurs when young rats are starved or are given a proteinfree diet (26).

It is interesting to consider the possible etiology of the differences found between our two groups of infants. Although it has been shown that rates of protein synthesis in rat fetuses change during the course of pregnancy $(27,28)$, there were no significant differences between our groups of neonates in gestational or postnatal ages to explain the different results. Other factors include infection (29) and trauma (30), which have been shown to increase synthesis and breakdown rates, but if these two factors had been operative one would expect the converse of what we found; namely, lower rates in the clinically sicker neonates. Those in group B were subject to more trauma, although unquantifiable, in that they received more intensive care procedures. Moreover, infection, although difficult to diagnose in neonates, was not detected. The most likely explanation of the difference between groups, however, is nutritional status. Malnutrition and lack of growth is associated with reduced rates of protein synthesis and breakdown in infants (31). It is probable, therefore, that these neonates differed in their intrauterine nutritional status and that group $\mathrm{B}$ had been growing more slowly. However, separation of the infants into weight groups for gestational age (appropriate or small) did not confirm this, which may only reflect the crude nature of the subdivision. Lower rates of protein synthesis have been found in small-for-gestational-age preterm infants, when compared with normally grown ones, but this was attributed to the significantly greater gestational age of the former (32).

The lower rates of turnover in group B neonates would result in a concomitant reduction in energy needs. This may be important for the stressed, sick, premature infant unable to tolerate as much energy in the form of glucose and fat or sufficient protein compared with their more healthy counterparts in the early postnatal days of life.

The differences in turnover rates between the two groups suggest that parameters of protein metabolism could be of use in assessing those infants in need of supplemental nutritional support by highlighting those infants who can be satisfactorily maintained on i.v. glucose alone until establishment of full enteral feeds, a process that may take several days in LBWN. There was little overlap between the groups in whole body protein synthesis rates. There was an even clearer separation of groups in the $\mathrm{N}$ excretion data, but only when appropriate correction was made for urea retention in the body water compartment. We would, therefore, suggest that the corrected rate of $\mathrm{N}$ excretion, in particular, could be useful in determining whether or not to start an individual neonate on TPN. Further studies are required to assess whether rates of protein metabolism have any predictive value for outcome.

\section{REFERENCES}

1. Adamkin DH 1986 Nutrition in very very low birth weight infants. Clin Perinatol 13:419-433

2. Raiha NCR, Heinonen K, Rassin DK, Gaull GE 1976 Milk protein quantity and quality in low birth weight infants. 1. Metabolic responses and effects on growth. Pediatrics 57:659-674

3. Heird WC, Dell RB, Driscoll JM, Grebin B, Winters RW 1972 Metabolic acidosis resulting from intravenous alimentation mixtures containing synthetic amino acids. N Engl J Med 287:943-948

4. Johnson JD, Albritton WO, Sunshine P 1972 Hyperammonaemia accompanying parenteral nutrition in newborn infants. J Pediatr $81: 154-161$

5. Fraser TE, Bier DM 1980 Essential amino acid turnover in the human newborn. Pediatr Res 14:571(abstr)

6. Pencharz PB, Steffen WP, Cochran W, Scrimshaw NS, Rand WM, Young VR 1977 Protein metabolism in human neonates: nitrogen-balance studies estimated obligatory losses of nitrogen and whole-body turnover of nitrogen. Clin Sci Mol Med 52:485-495

7. Waterlow JC, Garlick PJ, Millward DJ 1978 Protein Turnover in Mammalian Tissues and in the Whole Body. North Holland, Amsterdam, pp 301-325

8. De Benoist B, Abdulrazzak Y, Brooke OG, Halliday D, Millward DJ 1984 Measurement of whole body protein turnover in the preterm infant with intragastric infusion of $\mathrm{L}-\left[1-{ }^{13} \mathrm{C}\right]$ leucine and sampling of the urinary leucine pool. Clin Sci 66:155-164

9. Gairdner D, Pearson J 1971 A growth chart for premature and other infants. Arch Dis Child 46:783-787

10. Matthews DE, Schwarz HP, Yang RD, Motil KJ, Young VR, Bier DM 1982 Relationship of plasma leucine and ketoiscaproate using a $\mathrm{L}-\left[1-{ }^{13} \mathrm{C}\right]$ leucine infusion in man: a method for measuring human intracellular leucine tracer enrichment. Metabolism 31:1105-1112

11. Liu HY, Anderson GJ 1967 A method for quantitative and fractional urine collection. J Pediatr 70:276-279

12. Kopple JD, Coburn JW 1973 Metabolic studies of low protein diets in uraemia 1. Nitrogen and potassium. Medicine (Baltimore) 52:583-595

13. Munro HM, Fleck A 1969 Analysis of tissues and body fluids for nitrogenous constituents. In: Munro HN (ed) Mammalian Protein Metabolism, Vol 3. Academic Press, New York, pp 423-525

14. Paul AA, Southgate DAT 1985 McCance \& Widdowson's The Composition of Foods. HM Stationery Offices, London, p 281

15. Ziegler EE, O'Donnell AM, Nelson SE, Fomon SJ 1976 Body composition of the reference fetus. Growth 40:329-341

16. Yudkoff M, Nissim I 1986 Methods for determining the protein requirement of infants. Clin Perinatol 13:123-132

17. Jackson AA, Shaw JCL, Barber A, Golden MHN 1981 Nitrogen metabolism in preterm infants fed human donor breast milk. Pediatr Res 15:1454-1461

18. Pencharz PB, Clarke R, Papageorgiou A, Farri L 1989 A reappraisal of protein turnover values in neonates fed human milk or formula. Can J Physiol Pharmacol 67:282-286

19. Irving $\mathrm{CS}$, Lifschitz $\mathrm{CH}$, Wong WW, Boutton TW, Nicholas BL, Klein PD 1985 Characterization of $\mathrm{HCO}_{3}{ }^{-} / \mathrm{CO}_{2}$ pool sizes and kinetics in infants. Pediatr Res 19:358-363

20. Van Aerde JEE, Sauer PJJ, Pencharz PB, Canagarayar U, Beesley J, Smith JM, Swyer PR 1985 The effects of energy intake and expenditure on the recovery of ${ }^{13} \mathrm{CO}_{2}$ in the parenterally fed neonate during a 4-hour primed constant infusion of $\mathrm{NaH}^{13} \mathrm{CO}_{3}$. Pediatr Res 19:806-810

21. Clugston GA, Garlick PJ 1983 Recovery of infused $\left[{ }^{14} \mathrm{C}\right]$ bicarbonate as respiratory ${ }^{14} \mathrm{CO}_{2}$ in man. Clin Sci 64:231-233

22. Catzeflis C, Schutz Y, Micheli J-L, Welsch C, Arnaud MJ, Jequier E 1985 Whole body protein synthesis and energy expenditure in very low birth weight infants. Pediatr Res 19:679 687

23. Stack T, Reeds PJ, Preston S, Hay S, Lloyd DJ, Aggett PJ $1989{ }^{15} \mathrm{~N}$ tracer studies of protein metabolism in low birth weight preterm infants: a comparison of ${ }^{15} \mathrm{~N}$ glycine and ${ }^{15} \mathrm{~N}$ yeast protein hydrolysate and of human milkand formula-fed babies. Pediatr Res 25:167-172

24. Duffy B, Gunn T, Collinge J, Pencharz P 1981 The effects of varying protein quality and energy intake on nitrogen metabolism of parenterally fed very low birth weight $(<1600 \mathrm{~g})$ infants. Pediatr Res 15:1040-1044

25. Pencharz $P$, Duffy B 1986 The effect of feeding route (iv or oral) on the protein metabolism of the neonate. Arn J Clin Nutr 43:108-111

26. McNurlan NA, Fern EB, Garlick PJ 1982 Failure of leucine to stimulate protein synthesis in vivo. J Biochem 204:831-838

27. Millican PE, Vernon RG, Pain VM 1987 Protein metabolism in the mouse during pregnancy and lactation. J Biochem 248:251-257

28. Morton AJ, Goldspink DF 1986 Changes in protein turnover in rat uterus during pregnancy. Am J Physiol 250:E1 14-E120 
29. Tomkins AM, Garlick PJ, Schofield WN, Waterlow JC 1983 The combined effects of infection and malnutrition on protein metabolism in children. Clin Sci $65: 313-324$

30. Crane CW, Picou D, Smith R, Waterlow JC 1977 Protein turnover in patients before and after elective orthopedic operations. Br J Surg 64:129-133

31. Golden MHN, Waterlow JC, Picou D 1977 Protein tumover, synthesis and breakdown before and after recovery from protein-energy malnutrition. Clin Sci Mol Med 53:473-477

32. Micheli JL Catzeflis C Cauderay M, Arnaud MJ Calame A, Jequier E 1990 Protein turnover and postnatal growth in infants. In: Chapman TE, Berger R, Reijngoud DJ, Okken A (eds) Stable Isotopes in Paediatric Nutritional and Metabolic Research. Intercept Ltd., Andover, Hampshire, UK, pp 35-50

\section{Announcements}

\section{Call for Abstracts}

The American Pediatric Society and The Society for Pediatric Research announce the abstract deadline for the 1992 Annual Meeting (May 4-7, 1992, Convention Center, Baltimore, MD) has been set as January 3, 1992. For further information, contact: APS/SPR, 141 Northwest Point Blvd., P.O. Box 675, Elk Grove Village, IL 60009-0675, (708) 427-0205, FAX (708) 427-1305.

\section{Meeting Announcement}

The International Federation for Juvenile and Infantile Gynecology will hold its 10th World Congress of Pediatric and Adolescent Gynecology in Paris, France from May 21 through May 23, 1992. For further information and registration, contact: Convergences Gyn-Juv 92, 120 Avenue Gambetta, F-75020 Paris, France, FAX: (33) $1-40-31-01-65$. 